\title{
ANALYSIS OF CLUSTERIZATION AND NETWORKING PROCESSES IN DEVELOPING INTERMODAL TRANSPORTATION
}

\author{
GINTARAS SINKEVIČIUS, ROMUALDAS GINEVICIUS, \\ ALDONA JARAŠŪNIENĖ
}

\begin{abstract}
A B S T R A C T
Analysis of the processes of clusterization and networking draws attention to the necessity of integration of railway transport into the intermodal or multimodal transport chain. One of the most widespread methods of combined transport is interoperability of railway and road transport. The objective is to create an uninterrupted transport chain in combining several modes of transport. The aim of this is to save energy resources, to form an effective, competitive, attractive to the client and safe and environmentally friendly transport system.

Under the modern conditions of globalization and integration into the European Union, the processes of networking are becoming increasingly important. In the context of intensive changes in the life of the society and business development processes, networking processes inevitably make influence on intermodal transportation. Therefore, the processes of clusterization, networking and integration have a significant impact on international economic area, including the development of a single social, scientific, technological information and transport system.
\end{abstract}

KEY WORDS

Railwy transport, clusterizaton, intermodal transportation, internationalization, networking processes, globalisation, contrailer

DOI: 10.1515/emj-2016-0018
Corresponding authors:

Gintaras Sinkevičius JSC Lithuanian railways, Vilnius Gediminas Technical University

$$
\text { e-mail: }
$$
g.sinkevicius@litrail.It

Romualdas Ginevicius Faculty of Management Bialystok University of Technology

$$
\text { r.ginievicius@pb.edu.pl }
$$

Aldona Jarašūnienè JSC Lithuanian railways, Vilnius Gediminas Technical University

e-mail: aldona.jarasuniene@vgtu.It

\section{INTRODUCTION}

Under the conditions of modern social and economic development and technological advance, especially in the context of globalization, various networks are to be considered to be a very perspective and effective organization form (Melnikas, 2011).

With intensive processes of globalization, business environment is changing in the international arena, new specific needs of business entities are emerging with intensive development of economic ties in a different business and cultural environment. In terms of developing intermodal transportation, there is a shortage of new approaches and decisions and applications of new forms of organization for better coordination of the interests of business and intermodal transport. It is obvious that railway transport is traditionally more related to national railway networks and it is poorly developed in international arena and its operation is not coordinated due to the existing technical, organizational, technological obstacles among different regions of the world. These reasons preclude 
the increase of the effectiveness of the intermodal transport operation, also becoming more competitive in organizing the transportation process on long distances. Therefore, it is important to analyse the processes of clusterization and networking as an alternative to the development of intermodal transportation.

\section{THEORETIC ASPECTS OF CLUSTERIZATION AND NETWORKING PROCESSES}

The processes of networking and network development in various areas of activities, including intermodal transportation, raise new challenges in global and international arena, including the European Union.

One of the networking processes by developing intermodal transportation is related to the theory of communication network, in which the importance of communication and exchange of knowledge between the suppliers and clients is emphasized. This communication network is made of companies which are engaged in the manufacturing of a product or service, dissemination and provision of it (Johanson \& Mattsson, 1988).

According to the aforementioned theory, internationalization of the activity of a railway transport company means that the company is creating and developing its positions in the communication networks of foreign partners. This may be achieved in three possible ways: (1) by creating its positions in the communication networks of foreign partners - that is international expansion; (2) by expanding the positions and increasing the obligations in foreign networks in which the company already has its positions - that is penetration; (3) by increasing the coordination of the current positions in various communication networks abroad - that is international integration (Meyer, 2000; Coviello \& Munro, 1997). Research shows that communication networks are especially important in developing international activity in Eastern Europe, first of all, in post-Soviet countries (Карасев, 2008).

One of the main advantages of railway transport is related to the organization of transportation on long distances between large logistics and freight stocks in which large freight flows are transported and distributed, and their delivery to the final place of destination is organized. In this regard, it is expedient to draw the attention to the fact that the interoperability of railway and road transport may be expressed in expanding contrailer transportation. Contrailer transportation is organized by carrying semi-trailers on specialized railway platforms between large logistics centers operating on a single railway network.

One of the forms of the development of communication networks which is to be attributed to the direction of internalization and collaboration are the processes of clusterization, which are not included into the theory of networks and it is relevant to intermodal transport.

According to the theories on communication network the development of the company largely depends on the positions it takes, therefore, in this case the process of internalization of the operation of the company is explained on the basis of the interoperability of the company and market (network) characteristics (Meyer et al., 2000).

In analysing the theories of networking and networks it is necessary to define the concept of railway networks.

The concept of railway networks is defined as the body of a state or part of its railway networks, lines and railway junctions, lines or branch lines (Juškaitė et al., 2006).

By analysing the published resources on the causes of cluster creation one can state that it is expedient to implement the cluster initiative only where there are some problems in a certain sector of the market, which occurred due to limited collaboration that would be completed where certain subjects are connected into a cluster. The most frequent problems are: shortage of knowledge - market participants are short with knowledge about the opportunities of business development and collaboration in the market; shortage of communications - market participants have not made interrelations that would be useful in developing their activity and expanding into new markets; shortcoming of collaboration there is a shortage of private business, science institutions and public authorities collaboration (which works in different directions, joint opportunities are not used).

These problems are related to railway transport. Despite the fact that railway networks have been developed, however, they are usually limited to physical connection of railway infrastructure and organizations of train traffic.

The clusters of companies, institutions, various organizations operating at international level, as 
organizations of a network type, must be distinguished by certain characteristics (Melnikas, 2011).

One of the examples of clusters could be a single formation of railway, road transport and logistics service operator operating in a single system of information and international transportation and a single freight transportation market.

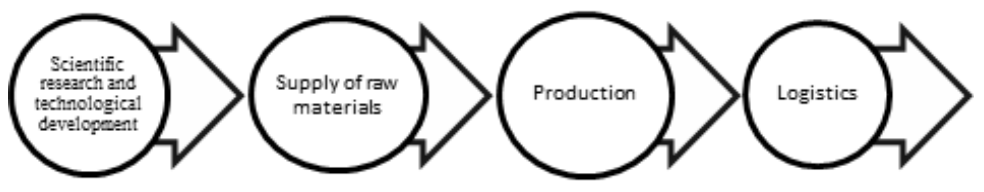

Fig. 1. A universal example of a value chain

Source: (Cluster study, 2012).

Jucevičius (2009) who has analysed the operation of clusters on an international scale singles out the role of a country in the formation of clusterization processes, which is often expressed by completing the functions of the main coordinator, which help coordinate the processes of the region or country, in which clusters are created.

Porter (1990) analysed the practice of operation of clusters in international trade networks and he draws attention to the contribution of the actions of the government, which are important in the creation of favourable conditions for business enterprises to operate both within the territory of their state by creating favourable conditions for business development, and in foreign countries by creating the conditions for business development having agreed with corresponding authorities of foreign countries on the conditions of development of business in them.

According to the conception of clusters of Porter, a number of scientists have developed their ideas in their works how cluster policy should be formed. For example, Dunning (1997) provides the list of measures of authorities that could help in developing a cluster. At the same time he also emphasizes the clusters are different, therefore, policy measures must be tailored to a concrete cluster.

Porter (1998) defines the conception of a cluster as a formation, in which companies of various sectors are intertwined, the activity of which is concentrated on concrete value chains from the areas, the participants of cluster direct their activities to which. According to Porter, one of the main conditions for the appearance of clusters and their efficiency is a value chain. In scientific resources this kind, universal value chain example is provided (Fig. 1).
Figure 1 depicts a value chain in the case of production, however, this value chain is also suitable for railway transport since it includes all the subjects participating in the transportation by railway process. Cluster management is one of the aspects, which are relevant in the creation of a railway transport cluster managed by a principle of a cluster (Jucevičius, 2009).

In terms of cluster guides, according to Jucevičius (2014), for management of clusters the usual management methods are not suitable since the networks of organizations and specialists are organized and operate according to other principles (Melnikas, 2011). Cluster management may have a variety of management centralization and decentralization and self-regulation forms. In this regard, centralization of railway and road transport sector activities and service provision processes and search for synergy processes may be relevant. Management focused on these processes could make conditions for the improvement of transportation services by connecting railway and road transport services into a single chain by organizing a continuous transportation process „From door to door”. Effective information and transportation process management in a single information and organization area may significantly improve the quality of transport services. To this end, solutions are necessary related to the search of proper organizational forms such as a cluster.

Analysing cluster management and its forms in the context of transportation services, attention should be drawn to the selection of an organizational form by evaluating the legal status, the nature of activity, functions, the conditions of administration (Jucevičius, 2014).

Cluster management activity groups are presented in Fig. 2.

Marketing and advertising must be implemented according to the objective of the cluster by equally advertising and introducing to the market all the services provided to the members of the cluster by revealing the uniqueness of the services of each of them, the quality and security. Training and qualification in the cluster are a very important element, which may ensure "growth" of all the members of the cluster on one level by using the same business organization methods, the same business and information exchange programmes, a single methodology of getting into the foreign markets and 


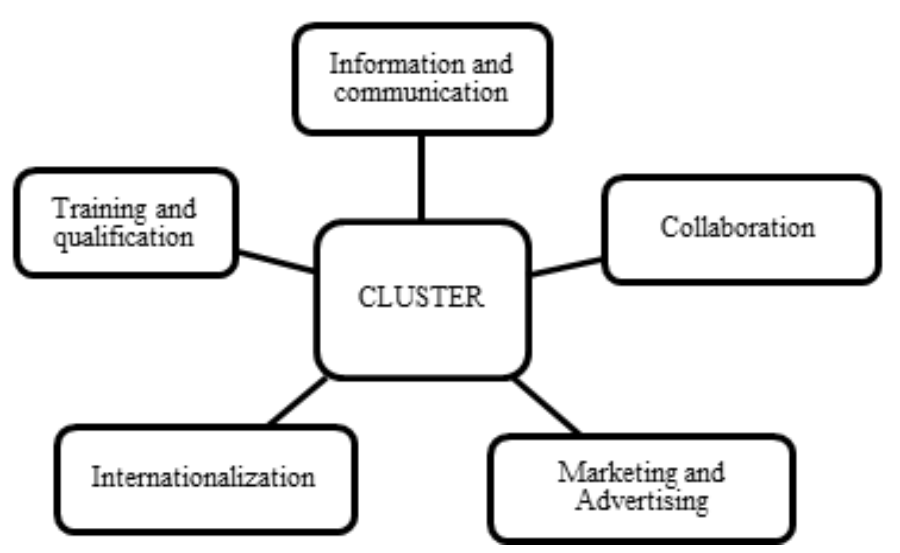

Fig. 2. The main groups of cluster management activities Source: (Cluster guide, 2012).

by applying single solutions for them to become enshrined (Сыздыкбаева, 2014).

Appearance of intermodal transport clusters is important for individual regions. Appearance of this type of clusters may give significant competitive advantages for the transport sector of the region and it would create opportunities for growth of value added of the region by integrating into the global

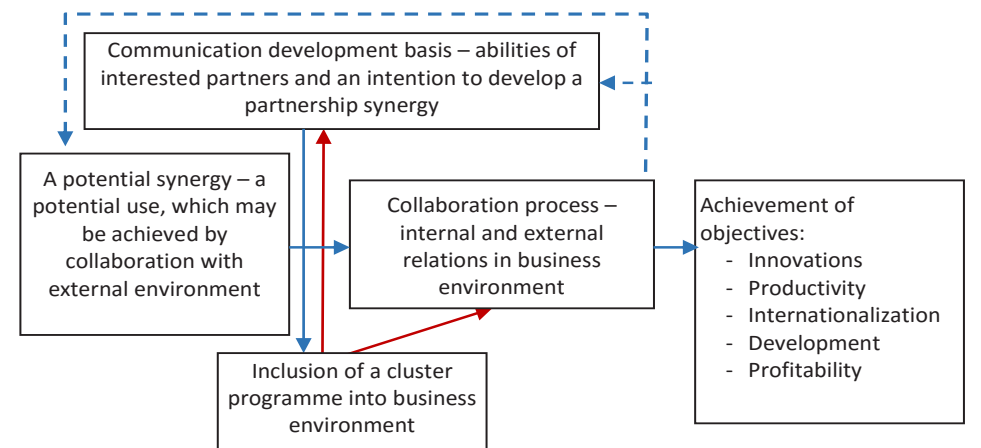

Fig. 3. Conceptual collaboration model based on a cluster ideology Source: (The Miami..., 2012). organization model for transit countries (Сыздыгбаева, 2014).

Figure 3 shows direct and constant relations between the subjects of the cluster, the relations that may appear in the long term perspective are pictured in dotted lines.

Another important aspect of collaboration is combining of resources (financial, mental, physical, etc.) The first aspect is innovations and international competitiveness - that of international (Cluster study, 2012). Improvement of competitiveness, relations between industry and science and appearance of new technologies. The second aspect is cluster growth - internal growth (for example, creation of new companies) and external growth (for example, new companies). The third element is the implementation of objectives - the level of implementation of objectives and meeting the deadlines, also the level of perception of activity initiatives.

One should note that the summary of clusterization and networking ideas and solutions allow making assumptions that these instead may have positive influence on the processes of development of intermodal transportation and may be expressed as an essential and very important factor in making business more active, by using the experience of the activities of new organizational forms. value added and economic activity networks and transport chains), (Элларян, http://www.e-rej.ru; Ellarian, 2014).

According to the analysis of the scientific literature, one can state the size of the formation of clusters must be decided by rationally selecting the interested business process participants that are interested in the formation of a cluster, by foreseeing strategic development and carrying out economic efficiency forecasts (Покофьева \& Элларян, http:/www.e-rej. $\mathrm{ru})$.

Some scientists note that the existence of clusters is an especially relevant and perspective business

\section{THE IMPORTANCE OF DEVELOPMENT OF INTERMODAL TRANSPORT}

Intermodal transport is defined as freight transportation by several modes of transport in a row from one mode of transport to another by reloading units of intermodal transport, but without overloading the very freights. Units of intermodal transport (UIT) are considered to be containers, semi-trailers of road transport or semi-trailers and the so called heating 
tanks.

Intermodal transportation by roads. Railway transport has three main advantages as opposed to road transport:

- it is competitive on long distances due to its economy of scale by transporting a large amount of UIT,

- it may reach a high speed,

- traffic jams, accidents, air conditions have little influence on railway transport and this increases its reliability.

Railways do not ensure punctual delivery either, even though they have a fundamental advantage against road transport with regard to traffic jams, accidents and air conditions. In practice it is noted that it is only less punctual than road transport due to the organizational reasons of railways. On average, only $40-50 \%$ of intermodal freights are delivered at the time scheduled.

In the global arena it is expedient to analyse international transportation chains, which in the context of internalization processes are the most relevant today in case of railway transport. Therefore, in the case of intermodal transportation cooperation is very important between different modes of transport, allowing implementation of a smooth transportation process in international and global network between the supporting points of logistics and freight distribution (Iskalijev, 2015). Intermodal transportations are an effective instrument for achieving a maximum ration of transportation service effectiveness and price in combining the modes of transport one can achieve the best transportation service result in terms of the price and quality.

To find out the extent of influence of the mode of transport and the benefit that each of them produces, one should analyse their interoperability as intermodality. Rodrigue (2012) single out the following characteristics of intermodality:

- Flexibility of usage. By using an intermodal mode of transport one can transport the assortment of various goods and multimodal freights;

- Management. To serve the system between the consignor and consignee one person is enough since the freight is not divided, and this grants an opportunity to speed up and facilitate the implementation of the tasks of the process. IT technologies significantly facilitate tracking of the freight, provide an opportunity to use the transportation time to the maximum to forecast further actions;

- Economy of scale. The price of transportation of the final product by transporting only by road transport, may reach 5-10\%, and by using intermodal transportation mode this indicator may be minimized to $1.5 \%$;

- The speed. Depending on the geographic location and the freight transported by using the advantages of various modes of transport, one can achieve maximum speed of freight transportation.

Fast intercontinental growth of trade has determined huge flows of freights. To achieve economy of scale, hub and spoke principle have been developed in freight transportation, freights are also transported between the main trade ports in very large quantities. This has determined the development of containerization, and that of intermodal transport.

The main container flows were formed from Asia to the West Coast of the USA and from Asia to the seaports of North Sea in Europe. Back flow of containers is nearly twice smaller. This kind of imbalance creates a problem of returning of empty containers. Effective grouping of freights and distribution is becoming decisive in the world, when the transition is to sending smaller parcels and individual orders.

This kind of transportation has been developed in the European Union. However, by evaluating the perspectives of freight transportation on long distances, one should look closer at the advantages of this mode of transport and suggest using it as an effective mode of transportation between the railway corridors between interim logistics terminals. It is expedient to organize contrailer transportation according to the principle of shutter train run, since it would produce an effect on the increase of freight delivery effectiveness with regard to the time and delivery to door (Sinkevičius \& Jarašūnienè, 2015).

With intensive railway transport development processes in international arena, the most important railway transport areas play vital role, which mostly influence and are more intensively expressed. Those are intermodal transportation and logistics systems, in which railway transport sector plays an increasingly more significant role in serving the freight in international markets, as well as railway transport corridors connecting railway systems working in different regions in the world into a single system.

The role of railway transport in the system of intermodal transportation is determined by the level of integration of the railway transport into intermodal or transport chain. One of the most widespread modes of intermodal transport is the interoperability of railway and road transport. Its aim 
is to create an uninterrupted transport chain by combining railway and road transport modes. In the context of development of intermodal transport services an essential role is played by the international transportation junctions integrated into transport corridors, in which large scale freight flow redistribution and reprocessing processes are emerging (Vasiliauskas, 2004).

In case of intermodal transportation cooperation between different modes of transport is very important, which allows implementation of a smooth transportation process in the international and global network between supporting logistics and freight distribution points. Intermodal transportation is an effective instrument to achieve maximum transportation service efficiency and price result in terms of price and quality (Rodrigue, 2012).

The carried out analysis of literary sources has revealed that it would be expedient to develop this mode of intermodal transportation on international railway corridors and this could be one of the elements of improving railway transport services and competitiveness. One can state that development of this mode of transport may be analysed in the implementation of intermodal transportation operating in the form of a cluster.

In development of intermodal transportation technology as an effective transportation instrument and a part of the integration process of the Lithuanian railways are shuttle trains.

In analysing the effectiveness of transportation by shuttle trains and management of the transportation process in different railway system areas, one should mention essential differences existing in each of the railway systems and precluding from producing the necessary results.

By implementing an integrated planning in the corridor highly effective running of the shuttle trains can be achieved. In other words, by making an integrated even distribution of the capacity of the entire corridor one can achieve a regular running of shuttle trains. This would provide railway transport a significant competitive advantages.

For analysing the use of shuttle trains for freight transportation, especially in the system of wide railway gauge, there is a shortage of academic sources, research works. According to practical experience it can be assumed that freight transportation by shuttle trains is not economically effective for railway companies or carriers, however, in terms of management, especially in the global context, in organizing multimodal business process by transporting freights between large logistics terminals, such trains determine an essential advantage with regard to the quality, punctuality and client evaluation.

Under the conditions of modern globalization with international trade and intermodal transportation becoming more intensive in the global market, global freight flows are becoming apparent, which need to be managed, distributed, reoriented and accumulated (Игнатьева, 2008).

The principles of effective transportation organization provided make a "5 S" system (speed, service, price, safety, stability), which are the main elements for the creation of a logistics system working in a global area. The essence of this system is that it is based on the principles of standardized logistics activities by creating a synergy effect in the sectors of logistics and railway transport by having reached a maximum possible interoperability level (Iskaliev, 2015)

Published sources state that the most effective process of transportation by railways and a high quality coordination of logistics processes is achieved if it is controlled in a coordinated way, who analysed the evolution of the logistics processes and development in the global area, provides a conception of a unified management of the logistics sector (Пехтерев, 2011).

It should be noted that the principles of management of the logistics sector provided by (Пехтерев, 2011) is related to the management of a certain logistics segment and freight flows, including management of transportation processes in railway corridors and chains of logistics terminals. By ensuring a complex management of the transportation process in freight transportation route, a high level of transportation by railways may be achieved.

By evaluating the development of railway transport in the context of logistics systems in Lithuania, it should be mentioned that Lithuania needs radical decisions for ensuring a complex interoperability of logistics and railway transport. The main objectives of improving the interoperability should be focused on the fact how to improve the integral aspect of the Lithuanian railway transport sector into logistics chains, to create a single data processing and management system that would be able to process the freight flows moving in the global arena, to create mechanisms that would help to ensure a high level mobility of freights by using the potential of the Lithuanian logistics infrastructure and to create convenient junctions with railway transport 
(Preparation..., 2011).

To summarize, it should be stated that the logistics system is important in the global arena in forming the decisions of the railway transport infrastructure and ensuring the development of the economic relations between large logistics and freight accumulation points of logistics terminals, by integrating the railway transport sector into global logistics, economic and transport communication networks. In the area of large scale logistics, an especially important element is the process of distribution of freight flow planning, which is based on consistent formation of freight flows, grouping and even distribution. This is also important for the distribution of the capacity, resources, throughput, etc. of transport services.

Another important area or object is the development of railway transport corridors in the context of railway transport expansion. Railway corridors are an effective instrument of transportation, information, technological processes, intermodal process management. Development of railway corridors suggest the need for creation of the necessary legal and technical conditions to substantiate their functioning and ensure the necessary level of competitiveness in the international transport system (Винокуров et al., 2009).

Railway corridors under the conditions of globalization and economic internalization have a role of the systems of transport junctions and freight flow movement arteries and are an element of integration of the global regions, connecting the markets and political systems. The system of railway corridors in the global arena has the function of connecting the logistics chains into a single system (Podberiozkina, 2015; Hibbs, 2003; Karrar, 2012).

One of the recent initiatives of the Russian Federation of recent years the development of the „Trans-Siberian Railway” by connecting the regions of Asia and Europe. Russia is intensively reinforcing the capacity of railway artery crossing the Russian territory and offers transit services (Бюлетень..., 2011; Brodin, 2002; Kissinger, 2009). According to academics, railway transport corridors are an effective tool for the restructurisation of the political and economic process worldwide. These processes are accompanied by the processes of trans-nationalization and integration (Лебедева, 2013). In this context, integration processes with focused orientation are formed in various regions of the world and supranational regulatory bodies emerge, which have got powers in the context of globalizations processes and may change the global trends of economy, international trade (Косолапов, 2005).

The regulation on freight corridor provides for technological interfaces with other modes of transport, that is circumstances are foreseen for planning freight reloading onto other modes of transport and their delivery „to door". High quality planning and ensuring compatibility is very important in aiming at greater railway transport attractiveness and reliability. These key elements usually determine clients' decision in choosing the mode of transport (White paper, 2011).

To further improve management of the railway corridor, the European Commission has expressed an initiative to establish a single traffic control centre, which would control train traffic in the entire EU transport TEN-T network. Currently, an infrastructure managers' platform has been established (CER, 2015).

The highest quality of the railway system interoperability is achieved when each of the railway companies participating in the corridor chain may provide a full spectrum of services, which makes the value chain of transportation by railways, which is usually applied in a continuous route. To ensure a high quality chain effectiveness, railway companies must coordinate their actions and decisions, to manage the transportation process and apply the planning methodology of the resource management joint actions.

Upon implementation of an integrated planning in the corridor, one may achieve a high degree of shuttle train operation effectiveness. By ensuring of an integrated even distribution of the capacity of the entire corridor, one can achieve a regular operation of trains. This would provide railway transport with competitive advantages (Gereffi \& Fernandez-Stark, 2011).

\section{CONCLUSIONS}

The analysis of the academic resources has shown that one of the most evident links of railway and road transport services may be contrailer transportation in combining railway and road transport systems into a single transportation process. Contrailer transportation is economically efficient since less material resources and time costs are needed to ensure this kind of transportation.

To ensure the development of this mode of transport, state assistance is needed as well as 
initiative of the private capital companies, agreement of the railway and road transport sectors on the division of activities and influence. For closer collaboration links to emerge, joint organizations measure are to be considered by connecting the railway and road transport service chain into a single system and to use the advantages of the organizational forms such as clusters in achieving the synergy allowing improvement of the quality of transportation service and organizing the provision of the service "from door to door" and to improve the effectiveness of the services by operating in a single information and organization area.

The most effective process of transportation by intermodal transport and coordination of high quality logistics processes is achieved when it is controlled in a coordinated way.

The logistics system is important in the global arena in forming the decisions of the railway transport infrastructure and ensuring the development of economic ties between large logistics and freight accumulation points. In the area of large scale logistics, the freight flow planning process is especially important, which is based on consistent formation of freight flows, grouping and even distribution. It is also important in distributing the capacity of transport service segment, resources, throughput, etc.

\section{LITERATURE}

Brodin, A. (2002). Breaking Loose? Russian reasons to end its dependence of foreign ports. The Nebi Yearbook 2001/2002, 123-146. doi: 10.1007/978-3-662-131817_8

Contessi, N. (2012). The new Silk Road diplomacy: China's Central Asian Foreign Policy since the Cold War. Central Asian Survey, 31(1): 99-113. doi: 10.1080/02634937.2011.603248

Coviello, N. E., \& Munro, H. J. (1997). Network Relationships and the Internationalization Process of Small Software Firms. International Business Review, 6(4), 361-386. doi:10.1016/S0969-5931(97)00010-3

Dunning, D., \& Sherman, D. A. (1997). Stereotypes and tacit inference. Journal of Personality and Social Psychology, 73(3), 459-471.

Элларян, А. Направления и особенности развития логистически - ориентированных кластерных образований в транспортном комплексе. Retrieved from http://www.e-rej.ru..upload.iblock/5 62/562f095acf920ac9b1a22c81ec4455ef.pdf
Gereffi, G., \& Fernandez-Stark, K. (2011). Global Value chain analysis: A primer. Nort Carolina, USA: Center on Globalisation, Governance and Competitivness (CGGC).

Hibbs, J. (2003). Transport Economics and politics: A practical Analysis of Performance, Efficiency and Marketing Objectives. London, Great Britain: Kogan Page Ltd.

Игнатьева, Н. А. (2008). Новые подходы к управлению закупочной деятельностью потребительской кооперации в целях повышения степени продовольственной самообеспеченности региона. Вестник Челябинского государственного универcumema, 29, 1994-2796.

Iskaliev, Y. S. (2015). Improving the competitiveness of the transit potential of the republic of Kazakhstan in the context of globalization of the world economy. Profile direction «6D052000 - Business Administration». Abstract of the dissertation on competition academic degree Doctor of Business Administration.

Johanson, J., \& Mattsson, L. G. (1988). Internationalization in industrial systems - a network approach. In N. Hood \& J. E. Vahlne (Eds), Strategies in Global Competition (pp. 303-321). New York, USA: Croom Helm.

Jucevičius, R. (2009). Klasterių vadovas. Vilnius, Lithuania: Klasterių kompetencijos tinklas.

Jucevičius, R., Kiškienè, A., Leichteris, E., \& Stumbrytė, G. (2012). Klasteriu studija. Vilnius, Lithuania: Asociacija „Žinių ekonomikos forumas”.

Jucevičius, R., Patašienè, I., \& Patašius, M. (2014). Digital Dimension of Smart City: Critical Analysis. Procedia - Social and Behavioral Sciences, 156(26), 146-150. doi:10.1016/j.sbspro.2014.11.137

Juškaitė, N., Keinys, S., \& Sakalauskas, K. K. (2006). Aiškinamasis geležinkelių terminu žodynas: terminai lietuviu, anglu, vokiečiu ir rusu kalbomis. Vilnius, Lithuania: Technika.

Kissinger, H. (2009). The world must forge a new order or retreat to chaos. Distributed by tribune media services Inc. Retrieved from http://www.independent. co.uk/voices/commentators/henry-kissinger-theworld-must-forge-a-new-order-or-retreat-to-chaos-1451416.html

Klaipėdos viešojo logistikos centro steigimas galimybių studijos parengimas (2011). Projektas Nr. 2815212010. Galutinè ataskaita.

Косолапов, Н. А. (2005). Пространственно-организационный подход к анализу международных реалий. Международные прочессы, 6, 1-3.

Лебедева, М. М. (2013). Ренесанс геополитики? Говорят эксперты МГИМО. Retrieved from http://old.mgimo.ru/news/experts/document237333.phtml

Melnikas, B. (2011). Transformacijų visuomene: ekonomika, kultūra, inovacijos, internacionalizavimo procesai. Vilnius, Lithuania: Technika.

Meyer, J., Spilsbury, K., \& Prieto, J. (2000). Comparison of findings from a single case in relation to those from a systematic review of action research. Nurse Researcher, 7(2), 37-59. doi: 10.7748/nr2000.01.7.2.37. c6114 
Пехтерев, Ф. С. (2011). О первом этапе разработки кониепиии развития сети железных дорог с шириной колеи 1520 мм. Бюллетень обьединенного ученого Совета ОАО «РЖД», №1.

Porter, M. A. (1990). The Competitive Advantage of Nations. New York, USA: Free Press, Inc.

Porter, M. A. (1998). Clusters and the New Economics of Competition. Harvard Business Review, NovemberDecember, 77-90.

Rodrigue, J. P. (2012). Supply Chain Management, Logistics Changes and the Concept of Friction. In P. V. Hall \& M. Hesse (Eds.), Cities, Regions and Flows (pp. 2842-2843). London, Great Britain: Routledge.

Sinkevičius, G., \& Jarašūniene, A. (2015). Development of Railway Transport in the Context of International Intermodal Transportation, Logistics and Transport Corridors. Proceedings of 19 th International Conference „Transport Means. 2015”.

Сыздыкбаева, Б. У. (2014). Основные методологические приниипь формирования транспортно логистического кластера. Retrieved from http:// www.enu.kz.repository/repository2014/osnovnyemetodologicheskie.pdf

Vasiliauskas, A. (2004). Strateginis valdymas. Kaunas, Lithuania: Technologija.

White Paper. Roadmap to a Single European Transport Area - Towards a competitive and resource efficient transport system. Brussels, 28.3.2011 COM(2011) 144 final. Retrieved from http://ec.europa.eu/transport/ themes/strategies/doc/2011_white_paper/white_paper_com(2011)_144_en.pdf

Винокуров, Е. Ю., Джадралиев, М. А., \& Щербанин, Ю. А. (2009). Международные транспортные коридоры ЕврАзЭС: быстрее, дешевле, больше. Евразийский банк развития. Отраслевой обзор. Март. Retrieved from http://transtec.transtec-neva. $\mathrm{ru} /$ files/File/eurozec.pdf 